\title{
Analysis of DWPF Sludge Batch 7a (Macrobatch 8) Pour Stream Samples
}

\author{
F.C. Johnson \\ J.M. Pareizs
}

October 2012

Savannah River National Laboratory Savannah River Nuclear Solutions, LLC Aiken, SC 29808

Prepared for the U.S. Department of Energy under contract number DE-AC09-08SR22470.

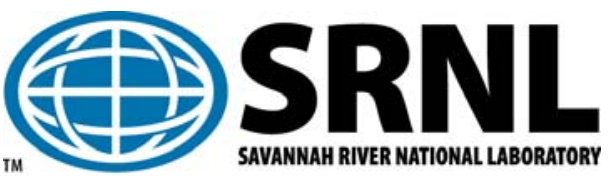




\section{DISCLAIMER}

This work was prepared under an agreement with and funded by the U.S. Government. Neither the U.S. Government or its employees, nor any of its contractors, subcontractors or their employees, makes any express or implied:

1. warranty or assumes any legal liability for the accuracy, completeness, or for the use or results of such use of any information, product, or process disclosed; or

2. representation that such use or results of such use would not infringe privately owned rights; or

3. endorsement or recommendation of any specifically identified commercial product, process, or service.

Any views and opinions of authors expressed in this work do not necessarily state or reflect those of the United States Government, or its contractors, or subcontractors.

\section{Printed in the United States of America \\ Prepared for \\ U.S. Department of Energy}


Keywords: $D W P F$,

Glass, Waste Compliance,

Sludge Batch $7 a$

Retention: Permanent

\title{
Analysis of DWPF Sludge Batch 7a (Macrobatch 8) Pour Stream Samples
}

\author{
F.C. Johnson
}

J.M. Pareizs

October 2012

Savannah River National Laboratory

Savannah River Nuclear Solutions, LLC Aiken, SC 29808

Prepared for the U.S. Department of Energy under contract number DE-AC09-08SR22470.

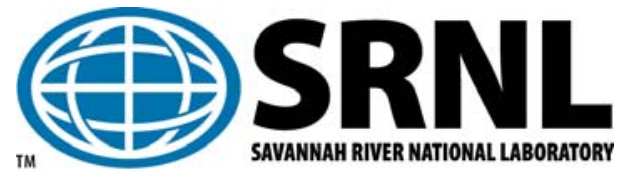




\section{REVIEWS AND APPROVALS}

AUTHORS:

F.C. Johnson, Process Technology Programs

Date

TECHNICAL REVIEW:

D.K. Peeler, Process Technology Programs

Date

C.L. Crawford, Process Technology Programs

Date

APPROVAL:

C.C. Herman, Manager

Date

Process Technology Programs

S.L. Marra, Manager

Date

Environmental \& Chemical Process Technology Research Programs

J.E. Occhipiniti, Manager

Date

Waste Solidification Engineering 


\section{ACKNOWLEDGEMENTS}

The author would like to acknowledge the support provided by the Shielded Cells Organization (Phyllis Burkhalter, Dee Wheeler, Rita Sullivan, Jane Howard and Monica Jenkins) as well as SRNL Analytical Development personnel (Damon Click, Boyd Wiedenman, Mark Jones, David Missimer, Henry Ajo, Ronnie Rutherford, Beverly Burch, Jack Durden, and Loretta Farrow) for the chemical analysis, REDOX measurement support, scanning electron microscopy and X-ray diffraction data. 


\section{EXECUTIVE SUMMARY}

The Defense Waste Processing Facility (DWPF) began processing Sludge Batch 7a (SB7a), also referred to as Macrobatch 8 (MB8), in June 2011. SB7a is a blend of the heel of Tank 40 from Sludge Batch 6 (SB6) and the SB7a material that was transferred to Tank 40 from Tank 51. SB7a was processed using Frit 418.

During processing of each sludge batch, the DWPF is required to take at least one glass sample to meet the objectives of the Glass Product Control Program (GPCP), which is governed by the DWPF Waste Compliance Plan, and to complete the necessary Production Records so that the final glass product may be disposed of at a Federal Repository. Three pour stream glass samples and two Melter Feed Tank (MFT) slurry samples were collected while processing SB7a. These additional samples were taken during SB7a to understand the impact of antifoam and the melter bubblers on glass redox chemistry. The samples were transferred to the Savannah River National Laboratory (SRNL) where they were analyzed. The following conclusions were drawn from the analytical results provided in this report:

- The sum of oxides for the official SB7a pour stream glass is within the Product Composition Control System (PCCS) limits (95-105 wt\%).

- The average calculated Waste Dilution Factor (WDF) for SB7a is 2.3. In general, the measured radionuclide content of the official SB7a pour stream glass is in good agreement with the calculated values from the Tank 40 dried sludge results from the SB7a Waste Acceptance Program Specification (WAPS) sample.

- As in previous pour stream samples, ruthenium and rhodium inclusions were detected by Scanning Electron Microscopy-Electron Dispersive Spectroscopy (SEM-EDS) in the official SB7a pour stream sample.

- The Product Consistency Test (PCT) results indicate that the official SB7a pour stream glass meets the waste acceptance criteria for durability with a normalized boron release of $0.64 \mathrm{~g} / \mathrm{L}$, which is an order of magnitude less than the Environmental Assessment (EA) glass.

- The measured density of the SB7a pour stream glass was $2.7 \mathrm{~g} / \mathrm{cm}^{3}$.

- The $\mathrm{Fe}^{2+} / \sum \mathrm{Fe}$ ratios of the SB7a pour stream samples were in the range of $0.04-0.13$, while the MFT sample glasses prepared by SRNL were in the range of $0.02-0.04$. 


\section{TABLE OF CONTENTS}

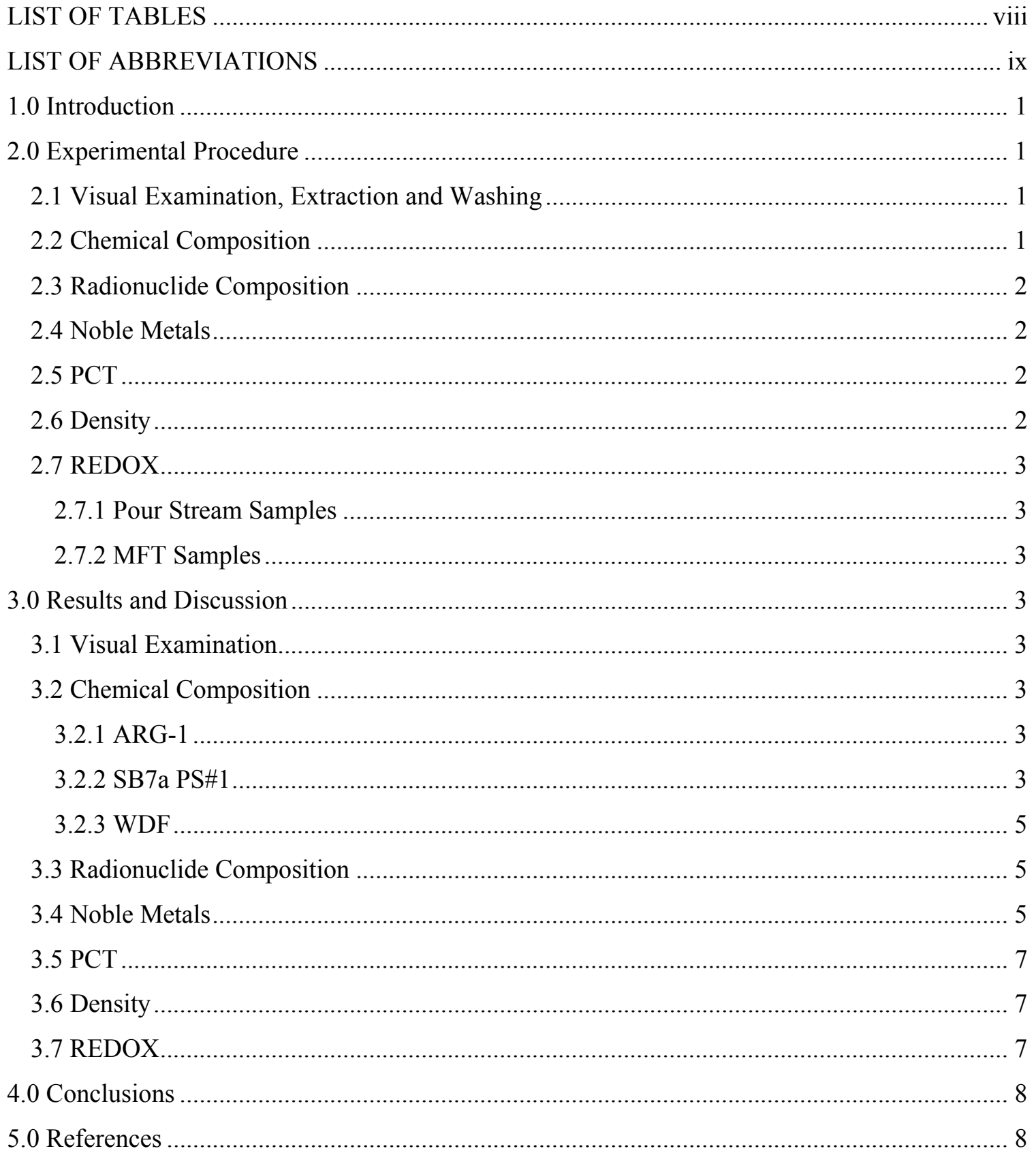




\section{LIST OF TABLES}

Table 1-1. DWPF Pour Stream Glass Sample Information................................................... 1

Table 3-1. Published ${ }^{19}$ and Measured Values of ARG-1 ........................................................... 4

Table 3-2. Average Measured Composition of SB7a PS\#1 ........................................................ 4

Table 3-3. Waste Dilution Factor for the SB7a PS\#1 Glass ........................................................ 5

Table 3-4. Reportable Radionuclide Concentration in the SB7a PS\#1 Glass ............................... 6

Table 3-5. Noble Metal Concentration in the SB7a PS\#1 Glass ................................................... 7

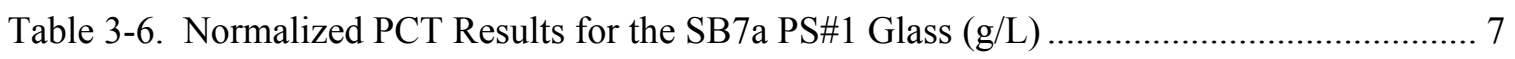

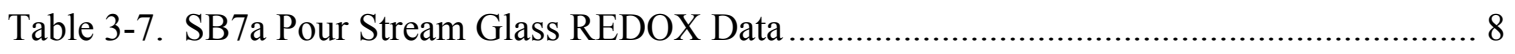

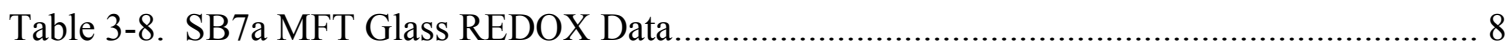

Table 5-1. Measured Elemental Concentrations ( $\mu \mathrm{g} / \mathrm{g}$ ) for Glasses Prepared Using a Mixed Acid

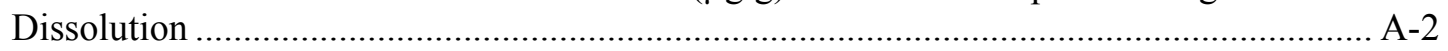

Table 5-2. Measured Elemental Concentrations ( $\mu \mathrm{g} / \mathrm{g}$ ) for Glasses Prepared Using a Peroxide

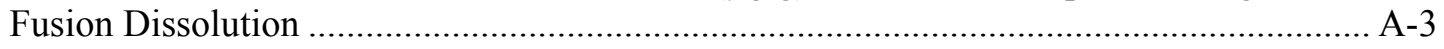

Table 5-3. As-Measured Radionuclide Concentrations (dpm/g) via Gamma and Beta Counting

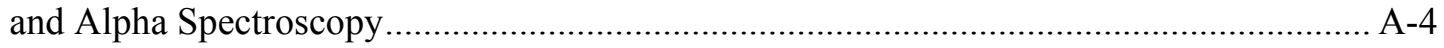

Table 5-4. As-Measured Tc-99 Concentrations (dpm/g) via Beta Counting Prepared Using a

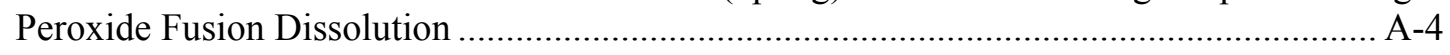

Table 5-5. Measured Tc-99 Concentrations (dpm/g) via Beta Counting Prepared Using a Mixed

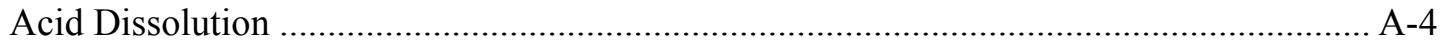

Table 5-6. As-Measured Concentrations of $\mathrm{m} / \mathrm{z}(\mu \mathrm{g} / \mathrm{g})$ via ICP-MS ..................................... A-5

Table 5-7. As-Received Measurements of the PCT Solutions ................................................. A-6

Table 5-8. As-Measured Concentrations of $\mathrm{m} / \mathrm{z}(\mu \mathrm{g} / \mathrm{L})$ via ICP-MS for the PCT Solutions ..... A-6

Table 5-9. As-Measured Radionuclide Concentrations (dpm/mL) via Gamma and Beta Counting

Table 5-10. Density Measurement Data .......................................................................... A-7

Table 5-11. SB7a Pour Stream Glass REDOX Data ............................................................. A-8

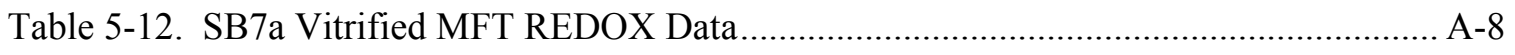




\section{LIST OF ABBREVIATIONS}

$\begin{array}{ll}\text { AD } & \text { Analytical Development } \\ \text { ARG-1 } & \text { Analytical Reference Glass-1 } \\ \text { ARM } & \text { Approved Reference Material } \\ \text { ASP } & \text { Analytical Study Plan } \\ \text { CPC } & \text { Chemical Process Cell } \\ \text { DWPF } & \text { Defense Waste Processing Facility } \\ \text { EA } & \text { Environmental Assessment } \\ \text { EDS } & \text { Electron Dispersive Spectroscopy } \\ \text { GPCP } & \text { Glass Product Control Program } \\ \text { IC } & \text { Ion Chromatography } \\ \text { ICP-AES } & \text { Inductively Coupled Plasma - Atomic Emission Spectroscopy } \\ \text { ICP-MS } & \text { Inductively Coupled Plasma - Mass Spectrometry } \\ \text { MB8 } & \text { Macrobatch 8 } \\ \text { MFT } & \text { Melter Feed Tank } \\ \text { PCCS } & \text { Product Composition Control System } \\ \text { PCT } & \text { Product Consistency Test } \\ \text { PF } & \text { Peroxide Fusion } \\ \text { PS } & \text { Pour Stream } \\ \text { REDOX } & \text { REDuction/OXidation } \\ \text { RSD } & \text { Relative Standard Deviation } \\ \text { SB } & \text { Sludge Batch } \\ \text { SEM } & \text { Scanning Electron Microscopy } \\ \text { SME } & \text { Slurry Mix Evaporator } \\ \text { SRAT } & \text { Sludge Receipt and Adjustment Tank } \\ \text { SRNL } & \text { Savannah River National Laboratory } \\ \text { St. Dev. } & \text { Standard Deviation } \\ \text { THERMO } & \text { Thermodynamic Hydration Energy Reaction MOdel } \\ \text { TTQAP } & \text { Task Technical and Quality Assurance Plan } \\ \text { WAPS } & \text { Waste Acceptance Product Specifications } \\ \text { WDF } & \text { Waste Dilution Factor } \\ \text { XRD } & \text { X-ray Diffraction } \\ & \end{array}$




\subsection{Introduction}

The Defense Waste Processing Facility (DWPF) began processing Sludge Batch 7a (SB7a), also referred to as Macrobatch 8 (MB8), in June 2011. SB7a is a blend of portions of material from Tanks 4, 7 and 12; the Sludge Batch 6 (SB6) heel in Tank 51; and a plutonium stream from $\mathrm{H}$ canyon. ${ }^{1,2}$ SB7a was processed using Frit 418.,4

Sludge is received into the DWPF Chemical Process Cell (CPC) and is processed through the Sludge Receipt and Adjustment Tank (SRAT) and Slurry Mix Evaporator (SME) tank. The treated sludge slurry is then transferred to the Melter Feed Tank (MFT) and fed to the melter. During processing of each sludge batch, the DWPF is required to take at least one glass sample to meet the objectives of the Glass Product Control Program ${ }^{5}$ (GPCP), which is governed by the DWPF Waste Form Compliance Plan, and to complete the necessary Production Records so that the final glass product may be disposed of at a Federal Repository.

The DWPF requested various analyses of radioactive glass samples obtained from the melter pour stream during processing of SB7a, as well as reduction/oxidation (REDOX) analysis of MFT samples to determine the impact of Argon bubbling and antifoam. ${ }^{6}$ Sample analysis followed the Task Technical and Quality Assurance Plan (TTQAP) ${ }^{7}$ and an Analytical Study Plan (ASP). ${ }^{8}$ Three Pour Stream (PS) glass samples and two MFT slurry samples ${ }^{a}$ were delivered to the Savannah River National Laboratory (SRNL) from the DWPF. Table 1-1 lists the sample information for each pour stream glass sample. SB7a PS\#1 was selected as the official pour stream sample for SB7a and full analysis was requested. This report details the visual observations of the as-received SB7a PS\#1 glass sample as well as results for the chemical composition, Product Consistency Test (PCT), radionuclide content, noble metals, and glass density. REDOX results will be provided for pour stream samples SB7a PS\#1 and \#3 and vitrified samples of MFT-580 and MFT-592. SB7a PS\#2 was designated as the archive sample and will be placed in Primary Container 117 (PC0117).

Table 1-1. DWPF Pour Stream Glass Sample Information

\begin{tabular}{|c|c|c|c|c|}
\hline Glass Canister & Sample Date & MFT Batch & Sample ID & Notes \\
\hline S03619 & Aug-11 & 580 & SB7a PS\#1 & Official \& REDOX \\
\hline S03623 & Aug-11 & 581 & SB7a PS\#2 & Archive \\
\hline S03677 & Oct-11 & 592 & SB7a PS\#3 & REDOX only \\
\hline
\end{tabular}

\subsection{Experimental Procedure}

\subsection{Visual Examination, Extraction and Washing}

Upon arrival at SRNL, pour stream samples SB7a PS\#1 and PS\#3 were inspected, removed from the $\mathrm{Pt} / \mathrm{Au}$ collection boats and washed according to procedure prior to analysis. ${ }^{9}$

\subsection{Chemical Composition}

A sample of SB7a PS\#1 was ground and then sieved to -200 mesh. Quadruplicate samples of the pour stream glass were digested by two separate methods: mixed acid ${ }^{10}$ (MA) and sodium peroxide fusion $^{11}(\mathrm{PF})$. Three Analytical Reference Glass (ARG-1) standards were also digested by each method and submitted along with the samples. All of the prepared samples were submitted to Analytical Development (AD) and analyzed by Inductively Coupled Plasma-Atomic

\footnotetext{
${ }^{a}$ MFT Batch 580 and MFT Batch 592, which will be denoted as MFT-580 and MFT-592 in the text.
} 
Emission Spectroscopy (ICP-AES). A multi-element standard and blank were also included in the analyses in order to assess the performance of the instrument over the course of the analyses.

\subsection{Radionuclide Composition}

The SB7a PS\#1 glass sample was prepared in quadruplicate using a PF digestion and was analyzed by AD using Inductively Coupled Plasma - Mass Spectroscopy (ICP-MS) to determine actinide and fission product content. Aliquots of the PF digestions were analyzed by counting methods and alpha spectroscopy to calculate the radionuclide concentration. ${ }^{\mathrm{b}}$ The reportable radionuclides for the GPCP and $\mathrm{WCP}^{12}$ not measured in this study were calculated from the SB7a total dried solids results using a calculated Waste Dilution Factor (WDF).

\subsection{Noble Metals}

Noble metal concentrations were analyzed in the SB7a PS\#1 sample using ICP-MS from the peroxide fusion dissolution. The total silver concentration is calculated using the measured concentration of ${ }^{109} \mathrm{Ag}$ and the calculated concentration of ${ }^{107} \mathrm{Ag} .{ }^{13}$ Due to interference from $\mathrm{Cd}$, the palladium concentration is calculated using the sum of the measured concentration of ${ }^{105} \mathrm{Pd}$ and the calculated concentrations of ${ }^{106} \mathrm{Pd},{ }^{107} \mathrm{Pd},{ }^{108} \mathrm{Pd}$, and ${ }^{110} \mathrm{Pd}$ using their fission yields. ${ }^{13}$ The total concentration of ruthenium is calculated from the sum of the measured concentrations of three isotopes: ${ }^{101} \mathrm{Ru},{ }^{102} \mathrm{Ru}$, and ${ }^{104} \mathrm{Ru}$. The reported concentration of rhodium is from the measured concentration of a single isotope, ${ }^{103} \mathrm{Rh}$.

In addition, a sample of SB7a PS\#1 (-200 mesh) was analyzed using Scanning Electron Microscopy (SEM) along with Energy Dispersive Spectroscopy (EDS) to image and analyze any inhomogeneities in the glass.

\section{$2.5 \underline{\mathrm{PCT}}$}

The PCT was performed on quadruplicate samples of SB7a PS\#1 to assess chemical durability using Method A of the procedure. ${ }^{14}$ Also included was the Environmental Assessment (EA) glass, the Approved Reference Material (ARM) glass and blanks from the sample cleaning batch. Samples were ground, washed and prepared according to standard procedure. ARM and EA were only prepared in triplicate. The resulting solutions were sampled (filtered and acidified) and analyzed by AD. Samples of a multi-element standard were also included with the glass samples as a check of the accuracy of the ICP-AES. Normalized release rates were calculated based on the measured composition using the average of the leachate concentrations.

\subsection{Density}

The density of SB7a PS\#1 was measured with a Hubbard-Carmick specific gravity bottle. By using the masses of the empty bottle $\left(m_{0}\right)$, bottle and sample $\left(m_{1}\right)$, bottle, sample and water $\left(m_{2}\right)$ and bottle and water $\left(m_{3}\right)$, the density of the sample $\left(\rho_{s}\right)$ is calculated by

$$
\rho_{s}=\frac{\rho_{H 2 O}\left(m_{1} m_{0}\right)}{\left(m_{3}-m_{0}\right)-\left(m_{2}-m_{1}\right)}
$$

where $\rho_{H 2 O}{ }^{c}$ is the density of water at the measurement temperature. A reference glass ${ }^{\mathrm{d}}$ was included in the set of measurements as an internal check of the measurement technique in the shielded cells.

\footnotetext{
${ }^{\mathrm{b}}$ The sample used for Tc-99 determination was prepared in quadruplicate using both the PF and MA digestions.

${ }^{c}$ The density of $\mathrm{H}_{2} \mathrm{O}$ was assumed to be $1 \mathrm{~g} / \mathrm{cm}^{3}$ for all measurements.
} 


\section{7 $\underline{\text { REDOX }}$}

\subsubsection{Pour Stream Samples}

A sample of SB7a PS\#1 and \#3 were ground and then sieved to -200 mesh. Both samples were prepared for REDOX measurement and analyzed via UV-Vis spectroscopy according to procedure. $^{15}$ In addition to the pour stream samples, the EA glass was included in each set of measurements as an internal check of the measured REDOX value.

\subsubsection{MFT Samples}

Both of the MFT slurry samples were prepared in triplicate and vitrified via the sealed crucible method according to procedure. ${ }^{16}$ All of the samples were removed from the alumina crucibles, ground and sieved to -200 mesh. The samples were then prepared and analyzed in a similar manner as the pour stream samples (Section 2.7.1).

\subsection{Results and Discussion}

\subsection{Visual Examination}

Upon receipt inspection, small regions on the surface of the SB7a PS\#1 appeared to be covered by a surface film; however, the bulk of the sample was black and shiny. Similar surface films have been observed on the surfaces of previous pour stream samples ${ }^{17,18}$ and have been attributed to salt deposits. There did not appear to be a surface film on the SB7a PS\#3 sample and the bulk of the sample was black and shiny.

\subsection{Chemical Composition}

Table 5-1 and Table 5-2 in Appendix A provide the measured elemental data from glasses prepared using mixed acid and peroxide fusion, respectively.

\subsubsection{ARG-1}

Table 3-1 shows a comparison of the published ${ }^{19}$ and measured composition of the ARG-1 glass. The measured value is the average of three replicates from either the mixed acid or peroxide fusion data as noted in the table. In general, the measured values are consistent with the published values; however, there was some variation in the measurement of $\mathrm{SiO}_{2}$ as shown by the Relative Standard Deviation (\%RSD). In addition, the average measured value of $\mathrm{SiO}_{2}$ is approximately $1.5 \mathrm{wt} \%$ higher than the target value. The sum of oxides is within the Product Composition Control System (PCCS) acceptance limits (the interval of 95 to $105 \mathrm{wt} \%$ ).

\subsubsection{SB7a PS\#1}

Table 3-2 lists the oxide composition of the SB7a PS\#1 glass. The measured value is the average of three replicates from either the mixed acid or peroxide fusion data as noted in the table. Some of the analytes were below the detection limit of the instrument and are noted by a result preceded by a "<." The \%RSD values for the major glass components $(>0.5 \mathrm{wt} \%)$ are less than $10 \%$, indicating good precision in the results.

\footnotetext{
${ }^{\mathrm{d}}$ The density of a sample of NIST 1830 glass was determined to be $2.48 \mathrm{~g} / \mathrm{cm}^{3}$ using the Archimedes method (ITS0057) prior to its placement in the shielded cells.
} 
Table 3-1. Published ${ }^{19}$ and Measured Values of ARG-1

\begin{tabular}{|c|c|c|c|c|}
\hline Oxide & $\begin{array}{c}\text { Publis hed } \\
\text { (wt\%) }\end{array}$ & $\begin{array}{c}\text { Meas ured } \\
\text { (wt\%) }\end{array}$ & \% RSD & $\begin{array}{c}\text { Digestion } \\
\text { Method }\end{array}$ \\
\hline $\mathrm{Al}_{2} \mathrm{O}_{3}$ & 4.73 & 4.66 & 0.2 & PF \\
\hline $\mathrm{B}_{2} \mathrm{O}_{3}$ & 8.67 & 8.18 & 0.8 & PF \\
\hline $\mathrm{BaO}$ & 0.09 & 0.09 & 1.6 & PF \\
\hline $\mathrm{CaO}$ & 1.43 & 1.43 & 1.5 & MA \\
\hline $\mathrm{Cr}_{2} \mathrm{O}_{3}$ & 0.09 & 0.10 & 0.8 & PF \\
\hline $\mathrm{Fe}_{2} \mathrm{O}_{3}$ & 14.0 & 13.98 & 0.3 & PF \\
\hline $\mathrm{K}_{2} \mathrm{O}$ & 2.71 & 2.59 & 0.7 & MA \\
\hline $\mathrm{Li}_{2} \mathrm{O}$ & 3.21 & 3.18 & 0.4 & PF \\
\hline $\mathrm{MgO}_{\mathrm{MnO}}$ & 0.86 & 0.87 & 0.7 & PF \\
\hline $\mathrm{Na}_{2} \mathrm{O}$ & 1.88 & 1.89 & 0.7 & PF \\
\hline $\mathrm{NiO}^{2}$ & 1.5 & 10.75 & 0.8 & MA \\
\hline $\mathrm{P}_{2} \mathrm{O}_{5}$ & 0.22 & 0.41 & 9.7 & PF \\
\hline $\mathrm{SiO}_{2}$ & 47.9 & 49.49 & 2.0 & PF \\
\hline $\mathrm{TiO}_{2}$ & 1.15 & 1.14 & 0.4 & PF \\
\hline $\mathrm{ZnO}$ & 0.02 & 0.02 & 1.1 & PF \\
\hline $\mathrm{ZrO}_{2}$ & 0.13 & 0.12 & 0.8 & MA \\
\hline $\mathrm{Total}$ & 99.64 & 99.94 & --- & --- \\
\hline
\end{tabular}

Table 3-2. Average Measured Composition of SB7a PS\#1

\begin{tabular}{|c|c|c|c|}
\hline Oxide & $\begin{array}{c}\text { Meas ure d } \\
\text { (wt\%) }\end{array}$ & \%RSD & $\begin{array}{c}\text { Digestion } \\
\text { Method }\end{array}$ \\
\hline $\mathrm{Al}_{2} \mathrm{O}_{3}$ & 8.59 & 2.6 & PF \\
\hline $\mathrm{B}_{2} \mathrm{O}_{3}$ & 4.27 & 2.9 & PF \\
\hline $\mathrm{BaO}$ & 0.05 & 3.0 & PF \\
\hline $\mathrm{BeO}$ & $<0.004$ & --- & PF \\
\hline $\mathrm{CaO}$ & 0.46 & 6.2 & MA \\
\hline $\mathrm{CdO}$ & 0.02 & 9.8 & PF \\
\hline $\mathrm{Ce}_{2} \mathrm{O}_{3}$ & $<0.14$ & --- & PF \\
\hline $\mathrm{Cr}_{2} \mathrm{O}_{3}$ & 0.07 & 9.5 & PF \\
\hline $\mathrm{CuO}_{2}$ & 0.40 & 3.9 & PF \\
\hline $\mathrm{Fe}_{2} \mathrm{O}_{3}$ & 8.37 & 2.9 & PF \\
\hline $\mathrm{Gd}_{2} \mathrm{O}_{3}$ & 0.05 & 7.4 & PF \\
\hline $\mathrm{K}_{2} \mathrm{O}$ & $<0.07$ & --- & MA \\
\hline $\mathrm{La}_{2} \mathrm{O}_{3}$ & 0.04 & 1.5 & PF \\
\hline $\mathrm{Li}_{2} \mathrm{O}$ & 4.56 & 2.8 & PF \\
\hline $\mathrm{MgO}_{20}$ & 0.27 & 3.4 & PF \\
\hline $\mathrm{MnO}$ & 2.01 & 2.7 & PF \\
\hline
\end{tabular}

\begin{tabular}{|c|c|c|c|}
\hline Oxide & $\begin{array}{c}\text { Meas ured } \\
\text { (wt\%) }\end{array}$ & \%RSD & $\begin{array}{c}\text { Digestion } \\
\text { Method }\end{array}$ \\
\hline $\mathrm{MoO}_{3}$ & $<0.08$ & --- & PF \\
\hline $\mathrm{Na}_{2} \mathrm{O}$ & 12.45 & 5.9 & MA \\
\hline $\mathrm{NiO}$ & 1.22 & 4.1 & PF \\
\hline $\mathrm{P}_{2} \mathrm{O}_{5}$ & $<0.39$ & --- & PF \\
\hline $\mathrm{PbO}$ & $<0.15$ & --- & PF \\
\hline $\mathrm{SO}_{4}$ & $<0.45$ & --- & MA \\
\hline $\mathrm{Sb}_{2} \mathrm{O}_{3}$ & $<0.25$ & --- & PF \\
\hline $\mathrm{SiO}_{2}$ & 47.07 & 2.8 & PF \\
\hline $\mathrm{SnO}_{2}$ & $<0.14$ & --- & PF \\
\hline $\mathrm{SrO}$ & 0.03 & 3.9 & PF \\
\hline $\mathrm{ThO}_{2}$ & 0.69 & 5.4 & PF \\
\hline $\mathrm{TiO}_{2}$ & 0.66 & 2.7 & PF \\
\hline $\mathrm{U}_{3} \mathrm{O}_{8}$ & 2.43 & 4.1 & PF \\
\hline $\mathrm{ZnO}_{2 n}$ & 0.09 & 4.0 & PF \\
\hline $\mathrm{ZrO}_{2}$ & 0.15 & 5.3 & MA \\
\hline $\mathrm{Total}^{2}$ & 95.65 & --- & --- \\
\hline
\end{tabular}




\subsubsection{WDF}

The WDF for a specific sludge batch is given by

$$
W D F(i)=\frac{C S(i)}{C G(i)}
$$

where $C S(i)$ is the concentration of component $i$ in the dried Tank 40 sludge $^{20}$ and $C G(i)$ is the concentration of component $i$ in the corresponding pour stream glass sample. Table 3-3 contains the calculated WDF values for $\mathrm{Al}, \mathrm{Ca}, \mathrm{Fe}$ and $\mathrm{Mn}$ for SB7a. The average WDF value will be used in Section 3.3 to calculate the concentration of radionuclides that were not directly measured in the glass.

Table 3-3. Waste Dilution Factor for the SB7a PS\#1 Glass

\begin{tabular}{|c|c|c|c|}
\hline \multirow{2}{*}{ Element } & \multicolumn{2}{|c|}{ Concentration (wt\%) } & \multirow{2}{*}{ WDF } \\
\cline { 2 - 3 } & Dried Sludge Slurry & Glass & \\
\hline $\mathrm{Al}$ & 10 & 4.55 & 2.2 \\
\hline $\mathrm{Ca}$ & 0.72 & 0.33 & 2.2 \\
\hline $\mathrm{Fe}$ & 14 & 5.86 & 2.4 \\
\hline $\mathrm{Mn}$ & 3.9 & 1.56 & 2.5 \\
\hline Average & --- & --- & 2.3 \\
\hline Std. Dev. & --- & --- & 0.1 \\
\hline
\end{tabular}

\subsection{Radionuclide Composition}

Based on measurements and analytical detection limits, twenty-five radionuclides were identified as reportable for DWPF SB7a (MB8) as specified by the Waste Acceptance Product Specification (WAPS). ${ }^{1,21, e, f}$ Selected radionuclides were directly measured in quadruplicate either by gamma counting, beta counting, alpha spectroscopy or ICP-MS. Table 3-4 lists the average concentrations of these radionuclides. ${ }^{\mathrm{g}}$ Table 5-3 through Table 5-6 in Appendix A provide the actual measured radiological chemical data and ICP-MS data, respectively. Some of the analytes were below the detection limit of the instrument and are noted by a result preceded with a " $<$." The content of each radionuclide was also calculated from measured values of the Tank 40 dried SB7a sludge and the average WDF value shown in Table 3-3. ${ }^{1}$

\subsection{Noble Metals}

The average measured concentrations of the noble metals based on quadruplicate measurements of SB7a PS\#1 are list in Table 3-5. Table 5-6 in Appendix A provides the actual measured ICPMS data. The calculated noble metal concentration in the glass is determined from the concentration in the Tank 40 sludge ${ }^{22}$ and the average WDF value (Table 3-3).

\footnotetext{
e Th-229 was identified as reportable for SB7a; however, there is no direct method for measuring its concentration, so its value will not be presented in this report. Based on the calculated values in SRNL-STI-2011-00720, Th-229 becomes reportable in the year 2515, which is of no practical significance to this study. Total $\mathrm{ThO}_{2}$ is reported in Table 3-2.

${ }^{\mathrm{f}}$ In addition to the twenty-five radionuclides identified above, U-235 and U-236 are also reportable per the requirements of the WAPS.

${ }^{\mathrm{g}}$ Th-232 was also added to the list as it was measured at greater than $0.2 \mathrm{wt} \%$ by ICP-MS.
} 
In addition to ICP-MS, the SB7a PS\#1 sample was also analyzed with SEM-EDS for noble metal inclusions. Examination of the glass with EDS indicated the presence of both $\mathrm{Ru}$ and $\mathrm{Rh}$, which corresponds to the results of the ICP-MS noble metals analysis in Table $3-5$. $^{\text {h }}$ Noble metal inclusions have been observed in previous pour stream samples, including SB4, SB5 and SB6. ${ }^{17,23}$

Table 3-4. Reportable Radionuclide Concentration in the SB7a PS\#1 Glass

\begin{tabular}{|c|c|c|c|}
\hline \multirow[t]{2}{*}{ Radionuclide } & $\begin{array}{l}\text { Tank } 40 \text { SB } 7 a \\
\text { Dried Sludge } \\
\end{array}$ & $\begin{array}{c}\text { Calculated } \\
\text { SB7a Glass } \\
\end{array}$ & $\begin{array}{c}\text { Me as ured SB7a } \\
\text { Glass }\end{array}$ \\
\hline & \multicolumn{3}{|c|}{$(\mathrm{Ci} / \mathbf{k g})$} \\
\hline $\mathrm{Ni}-59$ & $1.5 \mathrm{E}-03$ & $6.5 \mathrm{E}-04$ & -- \\
\hline $\mathrm{Ni}-63$ & $2.5 \mathrm{E}-02$ & $1.1 \mathrm{E}-02$ & --- \\
\hline Se-79 & $7.6 \mathrm{E}-06$ & $3.3 \mathrm{E}-06$ & --- \\
\hline Sr-90 & $1.4 \mathrm{E}+01$ & $6.1 \mathrm{E}+00$ & $3.9 \mathrm{E}+00$ \\
\hline Zr-93 & $5.3 \mathrm{E}-04$ & $2.3 \mathrm{E}-04$ & $5.4 \mathrm{E}-04$ \\
\hline $\mathrm{Nb}-93 \mathrm{~m}$ & $4.6 \mathrm{E}-04$ & $2.0 \mathrm{E}-04$ & --- \\
\hline Tc-99 & $1.0 \mathrm{E}-04$ & 4.3E-05 & $1.8 \mathrm{E}-05$ \\
\hline Sn-126 & $<6.4 \mathrm{E}-04$ & $<2.8 \mathrm{E}-04$ & --- \\
\hline Cs-137 & $5.9 \mathrm{E}-01$ & $2.6 \mathrm{E}-01$ & 4.3E-01 \\
\hline Sm-151 & $2.3 \mathrm{E}-01$ & $1.0 \mathrm{E}-01$ & --- \\
\hline Th-232 & $1.6 \mathrm{E}-06$ & $7.0 \mathrm{E}-07$ & $6.5 \mathrm{E}-07$ \\
\hline U-233 & $1.3 \mathrm{E}-04$ & $5.7 \mathrm{E}-05$ & $<2.4 \mathrm{E}-04$ \\
\hline U-234 & $4.8 \mathrm{E}-05$ & $2.1 \mathrm{E}-05$ & $<1.4 \mathrm{E}-04$ \\
\hline $\mathrm{U}-235$ & $6.4 \mathrm{E}-07$ & $2.8 \mathrm{E}-07$ & $2.9 \mathrm{E}-07$ \\
\hline U-236 & $1.1 \mathrm{E}-06$ & $4.8 \mathrm{E}-07$ & $<7.9 \mathrm{E}-07$ \\
\hline U-238 & $1.5 \mathrm{E}-05$ & $6.5 \mathrm{E}-06$ & $7.0 \mathrm{E}-06$ \\
\hline $\mathrm{Np}-237$ & $2.2 \mathrm{E}-05$ & $9.6 \mathrm{E}-06$ & $<1.9 \mathrm{E}-05$ \\
\hline $\mathrm{Pu}-238$ & $1.8 \mathrm{E}-01$ & $7.8 \mathrm{E}-02$ & $7.9 \mathrm{E}-02$ \\
\hline $\mathrm{Pu}-239$ & $1.3 \mathrm{E}-02$ & $5.7 \mathrm{E}-03$ & $6.1 \mathrm{E}-03$ \\
\hline $\mathrm{Pu}-240$ & $4.1 \mathrm{E}-03$ & $1.8 \mathrm{E}-03$ & $<4.5 \mathrm{E}-03$ \\
\hline $\mathrm{Pu}-241$ & $5.6 \mathrm{E}-02$ & $2.4 \mathrm{E}-02$ & $2.4 \mathrm{E}-02$ \\
\hline $\mathrm{Pu}-242$ & $<2.3 \mathrm{E}-05$ & $<1.0 \mathrm{E}-05$ & $<5.6 \mathrm{E}-05$ \\
\hline Am-241 & $3.7 \mathrm{E}-02$ & $1.6 \mathrm{E}-02$ & $1.5 \mathrm{E}-02$ \\
\hline Am-243 & $5.7 \mathrm{E}-04$ & $2.5 \mathrm{E}-04$ & --- \\
\hline $\mathrm{Cm}-244$ & $1.9 \mathrm{E}-02$ & $8.3 \mathrm{E}-03$ & --- \\
\hline $\mathrm{Cm}-246$ & 7.3E-06 & $3.2 \mathrm{E}-06$ & --- \\
\hline Cf-251 & $<9.2 \mathrm{E}-06$ & $<4.0 \mathrm{E}-06$ & --- \\
\hline $\begin{array}{l}\text { Alpha Sp } \\
\text { Beta Cou } \\
\text { Gamma } \\
\text { ICP-MS: }\end{array}$ & $\begin{array}{l}\text { ectroscopy: } \\
\text { nting: } \\
\text { lounting: }\end{array}$ & $\begin{array}{l}\mathrm{Pu}-238 \\
\text { Sr-90, Tc-99 and Pu- } \\
\text { Cs-137 and Am-241 } \\
\mathrm{Zr}-93 \text {, Th-232, U-23 } \\
\text { U-236, U-238, Np-2 } \\
240 \text { and } \mathrm{Pu}-242\end{array}$ & $\begin{array}{l}\text { J-234, U-235, } \\
\text { Pu-239, Pu- }\end{array}$ \\
\hline
\end{tabular}

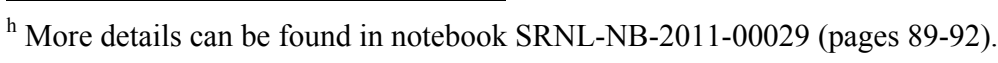


Table 3-5. Noble Metal Concentration in the SB7a PS\#1 Glass

\begin{tabular}{|c|c|c|c|}
\hline \multirow{2}{*}{ Noble Metal } & $\begin{array}{c}\text { Tank 40 SB7a } \\
\text { Dried Sludge }\end{array}$ & $\begin{array}{c}\text { Calculated } \\
\text { SB7a Glass }\end{array}$ & $\begin{array}{c}\text { Me as ured } \\
\text { SB7a Glass }\end{array}$ \\
\cline { 2 - 4 } & \multicolumn{3}{|c|}{$\mathbf{( w t \% )}$} \\
\hline $\mathrm{Ag}$ & 0.02 & 0.008 & 0.01 \\
\hline $\mathrm{Pd}$ & 0.003 & 0.001 & 0.003 \\
\hline $\mathrm{Rh}$ & 0.02 & 0.008 & 0.005 \\
\hline $\mathrm{Ru}$ & 0.09 & 0.04 & 0.03 \\
\hline
\end{tabular}

\section{5 $\underline{\mathrm{PCT}}$}

The average normalized release values for $\mathrm{ARM}^{\mathrm{i}}$, EA (published ${ }^{24}$ and measured) and SB7a PS\#1 are shown in Table 3-6. No water loss issues were observed over the course of the test. Table 5-7 through Table 5-9 ${ }^{\mathrm{j}}$ in Appendix A provides the as-received elemental leachate concentrations for the solutions samples generated by the PCTs. The normalized release values of the pour stream glass for $\mathrm{B}, \mathrm{Li}, \mathrm{Na}, \mathrm{Si}$ and $\mathrm{U}$ are below $1 \mathrm{~g} / \mathrm{L}$, which is very acceptable with respect to the EA glass benchmark values provided in Table 3-6.

Table 3-6. Normalized PCT Results for the SB7a PS\#1 Glass (g/L)

\begin{tabular}{|c|c|c|c|c|c|}
\hline Glas s ID & NL B & NL Li & NL Na & NL Si & NL U \\
\hline ARM & 0.47 & 0.55 & 0.49 & 0.28 & --- \\
\hline St. Dev. & 0.02 & 0.01 & 0.01 & 0.003 & --- \\
\hline \% RSD & 3.2 & 1.9 & 2.2 & 1.1 & --- \\
\hline EA - Me as ure d & 17.06 & 9.52 & 13.36 & 4.10 & --- \\
\hline St. Dev. & 0.10 & 0.13 & 0.04 & 0.01 & --- \\
\hline \% RSD & 0.6 & 1.3 & 0.3 & 0.2 & --- \\
\hline EA - Published & 16.7 & 9.6 & 13.3 & 3.9 & --- \\
\hline St. Dev. & 1.2 & 0.7 & 0.9 & 0.4 & --- \\
\hline \% RSD & 7 & 7 & 7 & 10 & --- \\
\hline SB7a PS\#1 & 0.64 & 0.71 & 0.97 & 0.48 & 0.15 \\
\hline St. Dev. & 0.01 & 0.01 & 0.03 & 0.01 & 0.01 \\
\hline \% RSD & 2.2 & 2.0 & 3.4 & 2.1 & 5.0 \\
\hline
\end{tabular}

\subsection{Density}

The density of the SB7a PS\#1 glass was determined to be $2.7 \mathrm{~g} / \mathrm{cm}^{3}$. Data from the density measurements are shown in Table 5-10 in Appendix A.

\subsection{REDOX}

Summaries of the REDOX results of the pour stream samples and vitrified MFT samples were communicated to DWPF in a series of brief memoranda. ${ }^{25-28}$ Table 3-7 and Table 3-8 list the average calculated values for $\mathrm{Fe}^{2+} / \sum \mathrm{Fe}$ and $\mathrm{Fe}^{2+} / \mathrm{Fe}^{3+}$ for the pour stream samples and MFT samples, respectively. Complete sets of data for each of the replicates and EA samples included with the individual sets are shown in Table 5-11 and Table 5-12 in Appendix A.

\footnotetext{
${ }^{\mathrm{i}}$ The concentrations of each element of interest for ARM were within the control limits stated in THERMO ${ }^{\mathrm{TM}}$.

${ }^{\mathrm{j}}$ As-measured radionuclide data is shown in Tables 5-8 and 5-9.
} 
Table 3-7. SB7a Pour Stream Glass REDOX Data

\begin{tabular}{|c|c|c|}
\hline Sample ID & $\mathbf{F e}^{2+} / \sum \mathbf{F e}$ & $\mathbf{F e}^{2+} / \mathbf{F e}^{3+}$ \\
\hline SB7a PS\#1 & 0.13 & 0.15 \\
\hline SB7a PS\#3 & 0.04 & 0.05 \\
\hline
\end{tabular}

Table 3-8. SB7a MFT Glass REDOX Data

\begin{tabular}{|c|c|c|}
\hline Sample ID & $\mathbf{F e}^{2+} / \sum \mathbf{F e}$ & $\mathbf{F e}^{2+} / \mathbf{F e}^{3+}$ \\
\hline MFT-580 & 0.04 & 0.04 \\
\hline MFT-592 & 0.02 & 0.02 \\
\hline
\end{tabular}

\subsection{Conclusions}

- The sum of oxides for the official SB7a pour stream glass is within the PCCS limits (95$105 \mathrm{wt} \%)$.

- The average calculated WDF for SB7a is 2.3. In general, the measured radionuclide content of the official SB7a pour stream glass is in good agreement with the calculated values from the Tank 40 dried sludge results from the SB7a WAPS sample.

- As in previous pour stream samples, ruthenium and rhodium inclusions were detected by SEM-EDS in the official SB7a pour stream sample.

- The PCT results indicate that the official SB7a pour stream glass meets the waste acceptance criteria for durability with a normalized boron release of $0.64 \mathrm{~g} / \mathrm{L}$, which is an order of magnitude less than the EA glass.

- $\quad$ The measured density of the SB7a pour stream glass was $2.7 \mathrm{~g} / \mathrm{cm}^{3}$.

- The $\mathrm{Fe}^{2+} / \sum \mathrm{Fe}$ ratios of the $\mathrm{SB} 7 \mathrm{a}$ pour stream samples were in the range of $0.04-0.13$, while the MFT sample glasses prepared by SRNL were in the range of $0.02-0.04$.

\subsection{References}

1. S.H. Reboul, D.P. DiPrete, D.R. Click, and C.J. Bannochie, "Reportable Radionuclides in DWPF Sludge Batch 7a (Macrobatch 8)," Savannah River National Laboratory, Aiken, SC, SRNL-STI-2011-00720, 2011.

2. J.M. Pareizs, A.L. Billings, and D.R. Click, "Sludge Washing and Demonstration of the DWPF Flowsheet in the SRNL Shielded Cells for Sludge Batch 7a Qualification," Savannah River National Laboratory, Aiken, SC, SRNL-STI-2011-00226, 2011.

3. C.C. Herman, D.K. Peeler, D.R. Click, J.M. Pareizs, and M.E. Stone, "Summary of SRNL Sludge Batch 7a Testing and Recommendations for DWPF Processing," Savannah River National Laboratory, Aiken, SC, SRNL-L3100-2011-00064, 2011. 
4. D.K. Peeler, T.B. Edwards, and A.L. Billings, "SB7a Recommendation: Based on SB7a Compositional Projections from 12-8-10," Savannah River National Laboratory, Aiken, SC, SRNL-L3100-2010-00248, 2010.

5. J.W. Ray, B.H. Culbertson, S.L. Marra, and M.J. Plodinec, "DWPF Glass Product Control Program," Washington Savannah River Company, Aiken, SC, WSRC-IM-91116-6, Rev. 6, 2006.

6. T.L. Fellinger, "Analysis of Sludge Batch 6 and 7 Pour Stream Samples," Savannah River Remediation, Aiken, SC, HLW-DWPF-TTR-2010-0047, 2010.

7. J.W. Amoroso and A.L. Billings, "Task Technical and Quality Assurance Plan for Analysis of Sludge Batch 6 and 7 Pour Stream Samples and Melter Feed Tank (MFT) Slurry Samples," Savannah River National Laboratory, Aiken, SC, SRNL-RP-201100104, 2011.

8. J.W. Amoroso and A.L. Billings, "Analytical Study Plan for Analysis of Sludge Batch 6 and 7 Pour Stream Samples and Melter Feed Tank (MFT) Slurry Samples," Savannah River National Laboratory, Aiken, SC, SRNL-RP-2011-00105, 2011.

9. C.J. Bannochie and N.E. Bibler, "Current and New Controls in the Shielded Cells for Handling DWPF Pour Stream Glasses and Comments Concerning S02244 and S02247 Glasses," Savannah River National Laboratory, Aiken, SC, SRNL-ITS-2005-00127, 2005.

10. “Acid Dissolution of Glass and Sludge for Elemental Analysis," Savannah River National Laboratory, Aiken, SC, ADS-2227, Latest Revision.

11. "Alkali Fusion Dissolutions of Sludge and Glass for Elemental and Anion Analysis," Savannah River National Laboratory, Aiken, SC, ADS-2502, Latest Revision.

12. "DWPF Waste Form Compliance Plan," Westinghouse Savannah River Company, Aiken, SC, WSRC-IM-91-116-0, Rev. 8, 2006.

13. N.E. Bibler, "Measuring and Predicting Fission Product Noble Metals in Savannah River Site High Level Waste Sludges," Westinghouse Savannah River Company, Aiken, SC, WSRC-TR-2005-0098, 2005.

14. "Nuclear Waste Glass and Glass-Ceramic Product Consistency Test (PCT) Methods (ASTM C1285 Latest Revision)," Savannah River National Laboratory, Aiken, SC, ITS0009, Latest Revision.

15. "Determining $\mathrm{Fe}^{2+} / \mathrm{Fe}^{3+}$ and $\mathrm{Fe}^{2+} / \mathrm{Fe}$ (Total) Using UV VIS Spectrometer," Savannah River National Laboratory, Aiken, SC, ITS-0042, Latest Revision.

16. "Heat Treatment of Waste Slurries for REDOX $\left(\mathrm{Fe}^{2+} / \mathrm{Fe}\right.$ Total) and Chemical Composition Measurement," Savannah River National Laboratory, Aiken, SC, ITS-0052, Latest Revision.

17. M.M. Reigel and N.E. Bibler, "Analysis of Sludge Batch 4 (Macrobatch 5) for Canister S02902 and Sludge Batch 5 (Macrobatch 6) for Canister S03317 DWPF Pour Stream 
Glass Samples," Savannah River National Laboratory, Aiken, SC SRNL-STI-201000435, 2010.

18. C.J. Bannochie and N.E. Bibler, "Analysis of Sludge Batch 3 (Macrobatch 4) DWPF Pour Stream Glass Sample for Canister S02312," Savannah River National Laboratory, Aiken, SC, WSRC-TR-2005-00354, 2005.

19. G.L. Smith, "Characterization of Analytical Reference Glass-1 (ARG-1)," Pacific Northwest National Laboratory, Richland, WA, PNL-8992, 1993.

20. S.H. Reboul and D.R. Click, "Stable Constituents in SB7a Tank 40 WAPS Sample," Savannah River National Laboratory, Aiken, SC, SRNL-L3100-2011-00133, 2011.

21. "Waste Acceptance Product Specifications for Vitrified High-Level Waste Forms," Department of Energy - Office of Environmental Management, Germantown, MD, DOE/EM-0093, Rev. 2, 1996.

22. C.J. Bannochie, "Tank 40 Final Chemical Characterization Results," Savannah River National Laboratory, Aiken, SC, SRNL-STI-2012-00097, Draft.

23. F.C. Johnson, "Analysis of DWPF Sludge Batch 6 (Macrobatch 7) Pour Stream Glass Samples," Savannah River National Laboratory, Aiken, SC, SRNL-STI-2011-00555, 2012.

24. C.M. Jantzen, N.E. Bibler, D.C. Beam, C.L. Crawford, and M.A. Pickett, "Characterization of the Defense Waste Processing Facility (DWPF) Environmental Assessment (EA) Glass Standard Reference Material," Westinghouse Savannah River Company, Aiken, SC, WSRC-TR-92-346, Rev. 1, 1993.

25. F.C. Johnson and D.R. Click, "REDOX Analysis of a SB7a Pour Stream Sample from MFT Batch 592," Savannah River National Laboratory, Aiken, SC, SRNL-L3100-201100233, 2011.

26. F.C. Johnson and D.R. Click, "REDOX Analysis of a Vitrified Sample from MFT Batch 592," Savannah River National Laboratory, Aiken, SC, SRNL-L3100-2011-00224, 2011.

27. F.C. Johnson, "REDOX Analysis of a Vitrified Sample from MFT Batch 580," Savannah River National Laboratory, Aiken, SC, SRNL-L3100-2011-00182, 2011.

28. F.C. Johnson, "REDOX Analysis of a SB7a Pour Stream Sample from MFT Batch 580," Savannah River National Laboratory, Aiken, SC, SRNL-L3100-2011-00181, 2011. 
SRNL-STI-2012-00017

Revision 1

Appendix A. Supplemental Data Tables 
Table 5-1. Measured Elemental Concentrations $(\mu \mathrm{g} / \mathrm{g})$ for Glasses Prepared Using a Mixed Acid Dissolution

\begin{tabular}{|c|c|c|c|c|c|c|c|c|c|c|c|c|c|c|c|}
\hline Lab ID & Al & $\mathbf{B a}$ & Be & $\mathrm{Ca}$ & $\mathbf{C d}$ & $\mathrm{Ce}$ & $\mathrm{Cr}$ & $\mathrm{Cu}$ & $\mathbf{F e}$ & Gd & $\mathbf{K}$ & La & $\mathbf{L i}$ & Mg & Mn \\
\hline 300293761 & 23300 & 778 & 24.2 & 10100 & 12.3 & $<118$ & 647 & 19.5 & 96700 & $<42$ & 21300 & $<10.5$ & 14900 & 5110 & 13800 \\
\hline 300293766 & 23100 & 782 & 24 & 10200 & 13.5 & $<118$ & 646 & 18.2 & 96300 & $<42$ & 21500 & $<10.5$ & 15000 & 5130 & 13900 \\
\hline 300294006 & 23200 & 794 & 24.2 & 10400 & 12.8 & $<131$ & 702 & 25.1 & 96300 & $<46.5$ & 21600 & $<11.7$ & 15100 & 5180 & 14000 \\
\hline 300293762 & 42300 & 342 & 2.39 & 3410 & 174 & 374 & 553 & 3250 & 62800 & 365 & $<599$ & 244 & 20000 & 1620 & 16000 \\
\hline 300293763 & 39900 & 257 & 2.39 & 3120 & 159 & 242 & 441 & 3050 & 59300 & 315 & 626 & 193 & 18800 & 1500 & 14800 \\
\hline 300293764 & 38800 & 284 & 2.37 & 3060 & 168 & 306 & 454 & 2940 & 60400 & 325 & $<594$ & 212 & 19100 & 1510 & 15500 \\
\hline 300293765 & 46000 & 187 & 2.4 & 3460 & 163 & 174 & 456 & 2950 & 59100 & 301 & $<602$ & 152 & 22200 & 1650 & 15400 \\
\hline 300293760 & $<66.4$ & 4.2 & $<1.6$ & 27.6 & 7.6 & $<121$ & $<20.4$ & $<12.6$ & 116 & $<43$ & $<602$ & $<10.8$ & $<29.2$ & 8.5 & $<10.6$ \\
\hline
\end{tabular}

\begin{tabular}{|c|c|c|c|c|c|c|c|c|c|c|c|c|c|c|c|}
\hline Lab ID & Mo & $\mathbf{N a}$ & $\mathbf{N i}$ & $\mathbf{P}$ & $\mathbf{P b}$ & $\mathbf{S}$ & Sb & $\mathbf{S i}$ & Sn & $\mathrm{Sr}$ & Th & Ti & $\mathbf{U}$ & $\mathbf{Z n}$ & $\mathbf{Z r}$ \\
\hline 300293761 & $<52.3$ & 80400 & 7920 & 1040 & $<140$ & $<1460$ & $<2080$ & 212000 & $<110$ & 31.2 & $<52.3$ & 6590 & $<6380$ & 163 & 901 \\
\hline 300293766 & $<52.3$ & 79200 & 7970 & 1060 & $<140$ & $<1460$ & $<2080$ & 218000 & $<110$ & 31.8 & $<52.3$ & 6640 & $<6380$ & 161 & 902 \\
\hline 300294006 & $<58$ & 79700 & 8040 & 1040 & $<155$ & $<1620$ & $<2310$ & 214000 & $<121$ & 32 & $<58$ & 6680 & $<7070$ & 164 & 914 \\
\hline 300293762 & $<53.4$ & 92000 & 10300 & 654 & $<143$ & $<1490$ & $<2120$ & 213000 & $<112$ & 174 & 4890 & 4240 & 22100 & 674 & 1220 \\
\hline 300293763 & $<53.4$ & 87000 & 9460 & 527 & $<143$ & $<1490$ & $<2120$ & 203000 & $<112$ & 152 & 3670 & 3910 & 21000 & 629 & 1100 \\
\hline 300293764 & $<53$ & 90400 & 9990 & 612 & $<142$ & $<1480$ & $<2110$ & 212000 & $<111$ & 153 & 4030 & 4100 & 21500 & 627 & 1160 \\
\hline 300293765 & $<53.6$ & 99900 & 9720 & 606 & $<143$ & $<1500$ & $<2130$ & 214000 & $<112$ & 147 & 2540 & 4010 & 20500 & 623 & 1090 \\
\hline 300293760 & $<53.6$ & $<1480$ & $<91$ & $<173$ & $<143$ & $<1500$ & $<213$ & 7170 & $<112$ & $<1$ & $<53.6$ & $<7.6$ & $<653$ & $<18.4$ & $<11$ \\
\hline
\end{tabular}


Table 5-2. Measured Elemental Concentrations $(\mu \mathrm{g} / \mathrm{g})$ for Glasses Prepared Using a Peroxide Fusion Dissolution

\begin{tabular}{|c|c|c|c|c|c|c|c|c|c|c|c|c|c|c|}
\hline Lab ID & Al & B & $\mathbf{B a}$ & Be & $\mathrm{Ca}$ & Cd & $\mathrm{Ce}$ & $\mathrm{Cr}$ & $\mathrm{Cu}$ & $\mathbf{F e}$ & Gd & $\mathbf{K}$ & La & $\mathbf{L i}$ \\
\hline 300293795 & 24700 & 25200 & 809 & 25 & 11600 & $<59.6$ & $<1160$ & 712 & $<121$ & 97500 & $<150$ & 21800 & $<129$ & 14700 \\
\hline 300293800 & 24600 & 25400 & 815 & 23.4 & 11800 & $<60.5$ & $<1180$ & 711 & $<123$ & 98100 & $<152$ & 21500 & $<131$ & 14800 \\
\hline 300294008 & 24700 & 25600 & 790 & 25.1 & 12100 & $<70.8$ & $<1380$ & 721 & $<144$ & 97700 & $<178$ & 21000 & $<153$ & 14800 \\
\hline 300293796 & 43700 & 12700 & 413 & $<15.7$ & 4780 & 140 & $<1190$ & 431 & 3080 & 56100 & 388 & $<5920$ & 354 & 20300 \\
\hline \begin{tabular}{|l|}
300293797 \\
\end{tabular} & 45900 & 13400 & 436 & $<15.9$ & 4930 & 145 & $<1200$ & 498 & 3330 & 59000 & 417 & $<5970$ & 351 & 21400 \\
\hline 300293798 & 45900 & 13500 & 438 & $<15.2$ & 4950 & 152 & $<1150$ & 542 & 3070 & 59100 & 447 & $<5720$ & 342 & 21400 \\
\hline \begin{tabular}{|l|}
300293799 \\
\end{tabular} & 46300 & 13500 & 441 & $<16$ & 5210 & 174 & $<1210$ & 476 & 3230 & 60100 & 458 & $<6020$ & 350 & 21600 \\
\hline 300293794 & 1210 & $<404$ & $<126$ & $<16$ & 1800 & $<62$ & $<1210$ & $<204$ & $<126$ & 152 & $<156$ & $<6020$ & $<134$ & $<292$ \\
\hline
\end{tabular}

\begin{tabular}{|c|c|c|c|c|c|c|c|c|c|c|c|c|c|c|c|}
\hline Lab ID & Mg & Mn & Mo & $\mathbf{N i}$ & $\mathbf{P}$ & $\mathbf{P b}$ & $\mathbf{S}$ & Sb & $\mathbf{S i}$ & Sn & $\mathrm{Sr}$ & Th & $\mathbf{T i}$ & $\mathbf{U}$ & $\mathbf{Z n}$ \\
\hline 300293795 & 5200 & 600 & 515 & 230 & 1670 & 1380 & $<14400$ & $<2050$ & 226000 & 1080 & 38. & 1050 & 67 & 6280 & 163 \\
\hline 300293800 & 5270 & 14700 & $<523$ & 8320 & $<1690$ & $<1400$ & $<14600$ & $<2080$ & 234000 & $<1100$ & 39.1 & $<1070$ & 6840 & $<6380$ & 160 \\
\hline 300294008 & 5220 & 14500 & $<612$ & 8200 & $<1980$ & $<1630$ & $<17100$ & $<2430$ & 234000 & $<1280$ & 43.4 & $<1250$ & 6800 & $<7450$ & 160 \\
\hline 300293796 & 1550 & 15000 & $<528$ & 9140 & $<1700$ & $<1410$ & $<14800$ & $<2100$ & 211000 & $<1100$ & 203 & 5620 & 3800 & 19700 & 654 \\
\hline 300293797 & 1630 & 15700 & $<532$ & 9460 & $<1720$ & $<1420$ & $<14900$ & $<2120$ & 222000 & $<1110$ & 218 & 6220 & 3980 & 20000 & 694 \\
\hline 300293798 & 1640 & 15700 & $<510$ & 9870 & $<1650$ & $<1360$ & $<14300$ & $<2030$ & 222000 & $<1070$ & 217 & 6210 & 3990 & 21300 & 719 \\
\hline 300293799 & 1680 & 16000 & $<536$ & 10000 & $<1730$ & $<1430$ & $<15000$ & $<2130$ & 225000 & $<1120$ & 222 & 6360 & 4040 & 21300 & 704 \\
\hline 300293794 & $<30$ & $<106$ & $<536$ & $<910$ & $<1730$ & $<1430$ & $<15000$ & $<2130$ & $<878$ & $<1120$ & $<10$ & $<1100$ & $<26$ & $<6530$ & $<96$ \\
\hline
\end{tabular}


Table 5-3. As-Measured Radionuclide Concentrations (dpm/g) via Gamma and Beta Counting and Alpha Spectroscopy

\begin{tabular}{|c|c|c|c|c|c|c|c|}
\hline Replicate & Glass ID & Lab ID & Am-241 & Cs-137 & Pu-238 & Pu-241 & Sr-90 \\
\hline 1 & \multirow{4}{*}{ SB7a PS\#1 } & 300294028 & $3.55 \mathrm{E}+07$ & $1.07 \mathrm{E}+09$ & $1.81 \mathrm{E}+08$ & $4.56 \mathrm{E}+07$ & $7.55 \mathrm{E}+09$ \\
\hline 2 & & 300294029 & $3.39 \mathrm{E}+07$ & $8.30 \mathrm{E}+08$ & $1.87 \mathrm{E}+08$ & $6.25 \mathrm{E}+07$ & $8.19 \mathrm{E}+09$ \\
\hline 3 & & 300294030 & $3.19 \mathrm{E}+07$ & $9.50 \mathrm{E}+08$ & $1.61 \mathrm{E}+08$ & $5.39 \mathrm{E}+07$ & $7.61 \mathrm{E}+09$ \\
\hline 4 & & 300294031 & $3.50 \mathrm{E}+07$ & $9.70 \mathrm{E}+08$ & $1.69 \mathrm{E}+08$ & $5.54 \mathrm{E}+07$ & $1.17 \mathrm{E}+10$ \\
\hline 1 & Blank & 300294027 & $3.42 \mathrm{E}+04$ & $<1.05 \mathrm{E}+07$ & $2.26 \mathrm{E}+06$ & $<1.74 \mathrm{E}+05$ & $<1.15 \mathrm{E}+08$ \\
\hline
\end{tabular}

Table 5-4. As-Measured Tc-99 Concentrations (dpm/g) via Beta Counting Prepared Using a Peroxide Fusion Dissolution

\begin{tabular}{|c|c|c|c|}
\hline \multirow{2}{*}{ Replicate } & \multirow{2}{*}{ Glass ID } & Lab ID & Tc-99 \\
\hline 1 & \multirow{4}{*}{ SB7a PS\#1 } & 300297002 & $3.90 \mathrm{E}+04$ \\
\cline { 4 - 4 } & & 300297003 & $3.92 \mathrm{E}+04$ \\
\cline { 4 - 4 } & & 300297004 & $4.30 \mathrm{E}+04$ \\
\hline 4 & & 300297005 & $3.97 \mathrm{E}+04$ \\
\hline 1 & Blank & 300297001 & $<1.79 \mathrm{E}+03$ \\
\hline
\end{tabular}

Table 5-5. Measured Tc-99 Concentrations (dpm/g) via Beta Counting Prepared Using a Mixed Acid Dissolution

\begin{tabular}{|c|c|c|c|}
\hline Replicate & Glass ID & Lab ID & Tc-99 \\
\hline 1 & \multirow{4}{*}{ SB7a PS\#1 } & 300297132 & $4.71 E+04$ \\
\hline 2 & & 300297133 & $4.28 \mathrm{E}+04$ \\
\hline 3 & & 300297134 & $3.73 \mathrm{E}+04$ \\
\hline 4 & & 300297135 & $3.64 \mathrm{E}+04$ \\
\hline 1 & Blank & 300297131 & $<1.73 \mathrm{E}+03$ \\
\hline
\end{tabular}


Table 5-6. As-Measured Concentrations of $\mathrm{m} / \mathrm{z}(\mu \mathrm{g} / \mathrm{g})$ via ICP-MS

\begin{tabular}{|c|c|c|c|c|c|c|c|c|c|}
\hline \multirow{2}{*}{ Replicate } & \multirow{2}{*}{ Glas s ID } & \multirow{2}{*}{ Lab ID } & \multicolumn{7}{|c|}{$\mathbf{m} / \mathbf{z}$} \\
\hline & & & 93 & 101 & 102 & 103 & 104 & 105 & 106 \\
\hline 1 & \multirow{4}{*}{ SB7a PS\#1 } & 300293796 & $2.11 \mathrm{E}+02$ & $1.38 \mathrm{E}+02$ & $1.21 \mathrm{E}+02$ & $4.88 \mathrm{E}+01$ & $7.05 \mathrm{E}+01$ & $<1.97 \mathrm{E}+01$ & $1.12 \mathrm{E}+02$ \\
\hline 2 & & 300293797 & $2.27 \mathrm{E}+02$ & $1.34 \mathrm{E}+02$ & $1.30 \mathrm{E}+02$ & $7.36 \mathrm{E}+01$ & $7.66 \mathrm{E}+01$ & $<1.98 \mathrm{E}+01$ & $7.60 \mathrm{E}+01$ \\
\hline 3 & & 300293798 & $2.12 \mathrm{E}+02$ & $1.30 \mathrm{E}+02$ & $1.13 \mathrm{E}+02$ & $3.57 \mathrm{E}+01$ & $7.54 \mathrm{E}+01$ & $<1.90 \mathrm{E}+01$ & $5.18 \mathrm{E}+01$ \\
\hline 4 & & 300293799 & $2.14 \mathrm{E}+02$ & $1.30 \mathrm{E}+02$ & $1.28 \mathrm{E}+02$ & $3.64 \mathrm{E}+01$ & $6.15 \mathrm{E}+01$ & $<2.00 \mathrm{E}+01$ & $7.80 \mathrm{E}+01$ \\
\hline 1 & Blank & 300293794 & $2.72 \mathrm{E}+01$ & $<1.50 \mathrm{E}+01$ & $<5.00 \mathrm{E}+00$ & $<5.17 \mathrm{E}+00$ & $<5.00 \mathrm{E}+00$ & $<2.00 \mathrm{E}+01$ & $3.37 \mathrm{E}+02$ \\
\hline
\end{tabular}

\begin{tabular}{|c|c|c|c|c|c|c|c|c|c|}
\hline \multirow{2}{*}{ Replicate } & \multirow{2}{*}{ Glas s ID } & \multirow{2}{*}{ Lab ID } & \multicolumn{7}{|c|}{$\mathbf{m} / \mathbf{z}$} \\
\hline & & & 107 & 108 & 109 & 110 & 232 & 233 & 234 \\
\hline 1 & \multirow{4}{*}{ SB7a PS\#1 } & 300293796 & $5.12 \mathrm{E}+01$ & $4.87 \mathrm{E}+01$ & $1.94 \mathrm{E}+01$ & $5.37 \mathrm{E}+01$ & $5.39 \mathrm{E}+03$ & $<2.46 \mathrm{E}+01$ & $<2.21 \mathrm{E}+01$ \\
\hline 2 & & 300293797 & $4.61 \mathrm{E}+01$ & $<3.22 \mathrm{E}+01$ & $2.09 \mathrm{E}+01$ & $4.26 \mathrm{E}+01$ & $5.77 \mathrm{E}+03$ & $<2.48 \mathrm{E}+01$ & $<2.23 \mathrm{E}+01$ \\
\hline 3 & & 300293798 & $2.60 \mathrm{E}+01$ & $3.15 \mathrm{E}+01$ & $<1.43 \mathrm{E}+01$ & $3.95 \mathrm{E}+01$ & $6.19 \mathrm{E}+03$ & $<2.38 \mathrm{E}+01$ & $<2.14 \mathrm{E}+01$ \\
\hline 4 & & 300293799 & $3.79 \mathrm{E}+01$ & $<3.25 \mathrm{E}+01$ & $2.06 \mathrm{E}+01$ & $4.60 \mathrm{E}+01$ & $6.20 \mathrm{E}+03$ & $<2.50 \mathrm{E}+01$ & $<2.25 \mathrm{E}+01$ \\
\hline 1 & Blank & 300293794 & $1.14 \mathrm{E}+02$ & $1.15 \mathrm{E}+02$ & $1.50 \mathrm{E}+01$ & $1.39 \mathrm{E}+02$ & $<1.75 \mathrm{E}+01$ & $<2.50 \mathrm{E}+01$ & $<2.25 \mathrm{E}+01$ \\
\hline
\end{tabular}

\begin{tabular}{|c|c|c|c|c|c|c|c|c|c|}
\hline \multirow{2}{*}{ Replicate } & \multirow{2}{*}{ Glass ID } & \multirow{2}{*}{ Lab ID } & \multicolumn{7}{|c|}{$\mathbf{m} / \mathbf{z}$} \\
\hline & & & 235 & 236 & 237 & 238 & 239 & 240 & 242 \\
\hline 1 & \multirow{4}{*}{ SB7a PS\#1 } & 300293796 & $1.23 \mathrm{E}+02$ & $<1.23 \mathrm{E}+01$ & $<2.71 \mathrm{E}+01$ & $1.95 \mathrm{E}+04$ & $9.57 \mathrm{E}+01$ & $<1.97 \mathrm{E}+01$ & $<1.48 \mathrm{E}+01$ \\
\hline 2 & & 300293797 & $1.40 \mathrm{E}+02$ & $<1.24 \mathrm{E}+01$ & $<2.73 \mathrm{E}+01$ & $2.05 \mathrm{E}+04$ & $9.66 \mathrm{E}+01$ & $<1.98 \mathrm{E}+01$ & $<1.49 \mathrm{E}+01$ \\
\hline 3 & & 300293798 & $1.42 \mathrm{E}+02$ & $<1.19 \mathrm{E}+01$ & $<2.61 \mathrm{E}+01$ & $2.15 \mathrm{E}+04$ & $1.05 \mathrm{E}+02$ & $<1.90 \mathrm{E}+01$ & $<1.43 \mathrm{E}+01$ \\
\hline 4 & & 300293799 & $1.39 \mathrm{E}+02$ & $<1.25 \mathrm{E}+01$ & $<2.75 \mathrm{E}+01$ & $2.20 \mathrm{E}+04$ & $9.70 \mathrm{E}+01$ & $<2.00 \mathrm{E}+01$ & $<1.50 \mathrm{E}+01$ \\
\hline 1 & Blank & 300293794 & $<1.00 \mathrm{E}+01$ & $<1.25 \mathrm{E}+01$ & $<2.75 \mathrm{E}+01$ & $1.75 \mathrm{E}+01$ & $<1.75 \mathrm{E}+01$ & $<2.00 \mathrm{E}+01$ & $<1.50 \mathrm{E}+01$ \\
\hline
\end{tabular}


Table 5-7. As-Received Measurements of the PCT Solutions

\begin{tabular}{|c|c|c|c|c|c|c|}
\hline \multirow{2}{*}{ Replicate } & \multirow{2}{*}{ Glass ID } & \multirow{2}{*}{ Lab ID } & \multicolumn{4}{|c|}{ As Received (mg/L) } \\
\hline & & & B & $\mathrm{Li}$ & $\mathrm{Na}$ & $\mathrm{Si}$ \\
\hline 1 & \multirow{3}{*}{ ARM } & 300296634 & 9.4 & 7.51 & 20.5 & 36.1 \\
\hline 2 & & 300296635 & 10.5 & 8.01 & 22.1 & 37.5 \\
\hline 3 & & 300296636 & 9.79 & 7.73 & 21.3 & 36.7 \\
\hline 1 & \multirow{3}{*}{ EA } & 300296631 & 36.6 & 11.7 & 101 & 56.7 \\
\hline 2 & & 300296632 & 35.9 & 11.3 & 100 & 56.3 \\
\hline 3 & & 300296633 & 36.1 & 11.2 & 101 & 56.3 \\
\hline 1 & \multirow{4}{*}{ SB7a PS\#1 } & 300296637 & 5.09 & 9.16 & 54.5 & 64.4 \\
\hline 2 & & 300296638 & 5 & 8.97 & 53.3 & 62.5 \\
\hline 3 & & 300296639 & 4.9 & 8.72 & 51.6 & 61.6 \\
\hline 4 & & 300296640 & 5.3 & 9.32 & 55.9 & 66.1 \\
\hline 1 & Soln Std & 300296641 & 19.8 & 9.67 & 82.2 & 51.9 \\
\hline 1 & \multirow{2}{*}{ Blank } & 300296629 & $<0.381$ & $<0.0584$ & $<2.95$ & $<0.391$ \\
\hline 2 & & 300296630 & $<0.381$ & $<0.0584$ & $<2.95$ & $<0.391$ \\
\hline
\end{tabular}

Table 5-8. As-Measured Concentrations of $\mathrm{m} / \mathrm{z}(\mu \mathrm{g} / \mathrm{L})$ via ICP-MS for the PCT Solutions

\begin{tabular}{|c|c|c|c|c|c|c|}
\hline \multirow{2}{*}{ Replicate } & \multirow{2}{*}{ Glass ID } & \multirow{2}{*}{ Lab ID } & \multicolumn{4}{|c|}{$\mathbf{m} / \mathbf{z}$} \\
\cline { 4 - 7 } & & & $\mathbf{9 9}$ & $\mathbf{2 3 3}$ & $\mathbf{2 3 4}$ & $\mathbf{2 3 5}$ \\
\hline 1 & & 300296637 & $<7.50 \mathrm{E}+00$ & $<5.00 \mathrm{E}+00$ & $<7.50 \mathrm{E}+00$ & $<1.75 \mathrm{E}+01$ \\
\hline \multirow{2}{*}{ SB7a PS\#1 } & 300296638 & $<7.50 \mathrm{E}+00$ & $<5.00 \mathrm{E}+00$ & $<7.50 \mathrm{E}+00$ & $<1.75 \mathrm{E}+01$ \\
\cline { 4 - 7 } & & 300296639 & $<7.50 \mathrm{E}+00$ & $<5.00 \mathrm{E}+00$ & $<7.50 \mathrm{E}+00$ & $<1.75 \mathrm{E}+01$ \\
\cline { 4 - 7 } & & 300296640 & $<7.50 \mathrm{E}+00$ & $<5.00 \mathrm{E}+00$ & $<7.50 \mathrm{E}+00$ & $<1.75 \mathrm{E}+01$ \\
\hline 4 & Blank & 300296629 & $<7.50 \mathrm{E}+00$ & $<5.00 \mathrm{E}+00$ & $<7.50 \mathrm{E}+00$ & $<1.75 \mathrm{E}+01$ \\
\hline 1 & & &
\end{tabular}

\begin{tabular}{|c|c|c|c|c|c|c|c|}
\hline \multirow{2}{*}{ Replicate } & \multirow{2}{*}{ Glas S ID } & \multirow{2}{*}{ Lab ID } & \multicolumn{5}{|c|}{$\mathbf{m} / \mathbf{z}$} \\
\cline { 4 - 8 } & & & $\mathbf{2 3 6}$ & $\mathbf{2 3 8}$ & $\mathbf{2 3 9}$ & $\mathbf{2 4 0}$ & $\mathbf{2 4 2}$ \\
\hline 1 & \multirow{3}{*}{ SB7a PS\#1 } & 300296637 & $<1.25 \mathrm{E}+01$ & $1.84 \mathrm{E}+03$ & $<5.00 \mathrm{E}+00$ & $<1.25 \mathrm{E}+01$ & $<5.00 \mathrm{E}+00$ \\
\cline { 4 - 8 } & & 300296638 & $<1.25 \mathrm{E}+01$ & $1.81 \mathrm{E}+03$ & $6.70 \mathrm{E}+00$ & $<1.25 \mathrm{E}+01$ & $<5.00 \mathrm{E}+00$ \\
\cline { 4 - 8 } & & 300296639 & $<1.25 \mathrm{E}+01$ & $1.66 \mathrm{E}+03$ & $7.54 \mathrm{E}+00$ & $<1.25 \mathrm{E}+01$ & $<5.00 \mathrm{E}+00$ \\
\cline { 4 - 8 } & & 300296640 & $<1.25 \mathrm{E}+01$ & $1.83 \mathrm{E}+03$ & $1.03 \mathrm{E}+01$ & $<1.25 \mathrm{E}+01$ & $<5.00 \mathrm{E}+00$ \\
\hline 4 & Blank & 300296629 & $<1.25 \mathrm{E}+01$ & $<5.00 \mathrm{E}+00$ & $<5.00 \mathrm{E}+00$ & $<1.25 \mathrm{E}+01$ & $<5.00 \mathrm{E}+00$ \\
\hline 1
\end{tabular}

Table 5-9. As-Measured Radionuclide Concentrations $(\mathrm{dpm} / \mathrm{mL})$ via Gamma and Beta Counting

\begin{tabular}{|c|c|c|c|c|}
\hline Replicate & Glass ID & Lab ID & Cs-137 & Sr-90 \\
\hline 1 & \multirow{4}{*}{ SB7a PS\#1 } & 300296637 & $1.36 \mathrm{E}+05$ & $2.02 \mathrm{E}+05$ \\
\hline 2 & & 300296638 & $1.40 \mathrm{E}+05$ & $1.10 \mathrm{E}+05$ \\
\hline 3 & & 300296639 & $1.38 \mathrm{E}+05$ & $1.19 \mathrm{E}+05$ \\
\hline 4 & & 300296640 & $1.61 \mathrm{E}+05$ & $2.97 \mathrm{E}+05$ \\
\hline 1 & Blank & 300296629 & $<4.24 \mathrm{E}+03$ & $<4.62 \mathrm{E}+03$ \\
\hline
\end{tabular}


Table 5-10. Density Measurement Data

\begin{tabular}{|c|c|c|}
\hline Parameter & NIST 1830 & SB7a PS\#1 \\
\hline $\mathrm{m} 0(\mathrm{~g})$ & 38.347 & 38.346 \\
\hline $\mathrm{m} 1(\mathrm{~g})$ & 43.39 & 46.402 \\
\hline $\mathrm{m} 2(\mathrm{~g})$ & 67.29 & 69.319 \\
\hline $\mathrm{m} 3(\mathrm{~g})$ & 64.256 & 64.257 \\
\hline Density $\left(\mathbf{g} / \mathbf{c m}^{\mathbf{3}}\right)$ & 2.51 & 2.69 \\
\hline
\end{tabular}


Table 5-11. SB7a Pour Stream Glass REDOX Data

\begin{tabular}{|c|c|c|c|c|c|c|}
\hline Sample ID & Replicate & $\mathbf{F e}^{\mathbf{2 +}}$ & $\sum \mathbf{F e}$ & $\mathbf{F e}^{3+}$ & $\mathbf{F e}^{\mathbf{2 +}} / \sum \mathbf{F e}$ & $\mathbf{F e}^{\mathbf{2 +}} / \mathbf{F e}^{\mathbf{3 +}}$ \\
\hline EA & --- & 0.093 & 0.526 & 0.433 & 0.177 & 0.215 \\
\hline \multirow{3}{*}{ SB7a PS\#1 } & 1 & 0.058 & 0.441 & 0.383 & 0.132 & 0.151 \\
\cline { 2 - 7 } & 2 & 0.055 & 0.375 & 0.320 & 0.147 & 0.172 \\
\cline { 2 - 7 } & 3 & 0.055 & 0.460 & 0.405 & 0.120 & 0.136 \\
\hline EA & --- & 0.1517 & 0.8235 & 0.6718 & 0.184 & 0.226 \\
\hline \multirow{3}{*}{ SB7a PS\#3 } & 1 & 0.0458 & 1.0664 & 1.0206 & 0.043 & 0.045 \\
\cline { 2 - 7 } & 2 & 0.0329 & 0.7584 & 0.7255 & 0.043 & 0.045 \\
\cline { 2 - 7 } & 3 & 0.0485 & 1.1006 & 1.0521 & 0.044 & 0.046 \\
\hline
\end{tabular}

Table 5-12. SB7a Vitrified MFT REDOX Data

\begin{tabular}{|c|c|c|c|c|c|c|}
\hline Sample ID & Replicate & $\mathbf{F e}^{2+}$ & $\sum \mathbf{F e}$ & $\mathbf{F e}^{3+}$ & $\mathbf{F e}^{2+} / \sum \mathbf{F e}$ & $\mathbf{F e}^{2+} / \mathbf{F e}^{3+}$ \\
\hline EA & --- & 0.094 & 0.497 & 0.403 & 0.189 & 0.233 \\
\hline \multirow{3}{*}{ MFT-580-A } & 1 & 0.011 & 0.396 & 0.385 & 0.028 & 0.029 \\
\cline { 2 - 7 } & 2 & 0.013 & 0.469 & 0.456 & 0.028 & 0.029 \\
\cline { 2 - 7 } & 3 & 0.012 & 0.379 & 0.367 & 0.032 & 0.033 \\
\hline \multirow{3}{*}{ MFT-580-B } & 1 & 0.022 & 0.607 & 0.585 & 0.036 & 0.038 \\
\cline { 2 - 7 } & 2 & 0.026 & 0.669 & 0.643 & 0.039 & 0.040 \\
\cline { 2 - 7 } MFT-580-C & 3 & 0.02 & 0.409 & 0.389 & 0.049 & 0.051 \\
\cline { 2 - 7 } & 1 & 0.025 & 0.547 & 0.522 & 0.046 & 0.048 \\
\hline \multirow{3}{*}{ EA } & 2 & 0.026 & 0.456 & 0.430 & 0.057 & 0.060 \\
\hline & --- & 0.018 & 0.384 & 0.366 & 0.047 & 0.049 \\
\cline { 2 - 7 } & 1 & 0.1729 & 0.9417 & 0.7688 & 0.184 & 0.225 \\
\cline { 2 - 7 } & 2 & 0.0224 & 1.1181 & 1.0957 & 0.020 & 0.020 \\
\hline \multirow{3}{*}{ MFT-592-B } & 3 & 0.0238 & 1.0321 & 1.0083 & 0.023 & 0.024 \\
\cline { 2 - 7 } & 2 & 0.0207 & 1.0168 & 0.9961 & 0.020 & 0.021 \\
\cline { 2 - 7 } & 3 & 0.0244 & 0.9740 & 0.9496 & 0.025 & 0.026 \\
\hline \multirow{3}{*}{ MFT-592-C } & 2 & 0.0209 & 0.9800 & 0.9591 & 0.021 & 0.022 \\
\cline { 2 - 7 } & 3 & 0.0254 & 0.9999 & 0.9745 & 0.025 & 0.026 \\
\hline
\end{tabular}




\section{Distribution:}

J.W. Amoroso, 999-W

C. J. Bannochie, 773-42A

J. M. Bricker, 704-27S

M. A. Broome, 704-29S

C.L. Crawford, 773-42A

T.B. Edwards, 999-W

H.H. Elder, 704-24S

T. L. Fellinger, 704-26S

S. D. Fink, 773-A

K.M. Fox, 999-W

E.J. Freed, 704-S

B. J. Giddings, 786-5A

J. M. Gillam, 766-H

C. C. Herman, 999-W

R. N. Hinds, 704-S

E. W. Holtzscheiter, 704-15S

J. F. Iaukea, 704-30S

P. R. Jackson, DOE-SR, 703-46A

C.M. Jantzen, 773-A

F.C. Johnson, 999-W

M. T. Keefer, 766-H

D.P. Lambert, 999-W

S. L. Marra, 773-A

D.W. McIlmoyle, 766-H

J.D. Newell, 999-W

J.E. Occhipinti, 704-S

J.M. Pareizs, 773-A

D. K. Peeler, 999-W

F. M. Pennebaker, 773-42A

J. W. Ray, 704-S

H. B. Shah, 766-H

D. C. Sherburne, 704-S

A. V. Staub, 704-27S

M. E. Stone, 999-W

K. H. Subramanian, 766-H

J. P. Vaughan, 773-41A

W. R. Wilmarth, 773-A

J.R. Zamecnik, 999-W 